Eksergi, Vol 17, No. 2. 2020

ISSN: $1410-394 \mathrm{X}$

\title{
Process Dynamic of Two-Thermal-Tank-Series with Dead Time
}

\author{
Yulius Deddy Hermawan*, Wibiana Wulan Nandari, Fauzan Irfandy, Riski Ajin Rahmadi, and Aryandhanu Mukti Tri \\ Perkasa \\ Department of Chemical Engineering, Faculty of Industrial Engineering, Universitas Pembangunan Nasional “Veteran” \\ Yogyakarta, Jl. SWK 103 (Lingkar Utara) Condongcatur Yogyakarta 55283, Indonesia.
}

\section{Artikel histori : \\ Diterima 2 September 2020 Diterima dalam revisi 28 Oktober 2020 Diterima 30 Oktober 2020 Online 31 Oktober 2020}

\begin{abstract}
ABSTRAK: Sistem multi-tangki-seri dapat menimbulkan masalah ketidak-stabilan akibat dead-time. Tujuan penelitian ini adalah untuk mempelajari kelakuan dinamis Dua-TangkiTermal-Seri (DTTS) dengan dead-time melalui percobaan loop terbuka di laboratorium, dan untuk mengajukan modul-baru praktikum dasar teknik kimia bidang dinamika proses untuk program sarjana. Dua pemanas-tanki-berpengaduk @10L dirancang untuk pemanasan fluida air. Kedua tangki dirancang over-flow agar volume cairannya selalu konstan. Valve dipasang pada pipa inlet Tank-1 untuk mengatur laju alir volumetrik fluida $(f)$. Suhu fluida masuk Tank$1\left(T_{1}\right)$, suhu cairan di dalam Tank-1 $\left(T_{2}\right)$ and Tank-2 $\left(T_{3}\right)$ diukur dengan thermocouple multichannels. Volt-ampere-regulator digunakan untuk mengatur energi pemanas listrik Tank-1 $\left(q_{1}\right)$ and Tank-2 $\left(q_{2}\right)$. Model matematika diselesaikan dan diuji dengan Xcos/Scilab. Untuk mempelajari kelakuan dinamis DTTS, gangguan laju alir dibuat berdasarkan perubahan input step. Berdasarkan pengamatan di laboratorium dan simulasi loop terbuka, Tank-1 danTank-2 menghasilkan respon stabil, respon model menunjukkan kedekatan dan perilaku yang sama dengan respon laboratorium, dan dead time 30 detik dijumpai di Tank-2.
\end{abstract}

Kata Kunci: dead time; loop terbuka; step input; DTTS; Xcos

ABSTRACT: The multi-tank-series system could come up the problem of instability due to dead-time. The goals of this work are to study the dynamic behavior of Two-Thermal-TanksSeries (TTTS) with dead time through the open loop experiment in laboratory, and to propose the new-module of fundamental chemical engineering practicum in field of process dynamic for undergraduate program. The two stirred-tank-heaters @10L were designed for heating of water fluid. Both of tanks were designed overflow to maintain their volume constant. The gate valve was installed in the inlet pipe of Tank-1 to adjust its volumetric flowrate $(f)$. The inlet temperature of Tank-1 $\left(T_{1}\right)$, the liquid temperatures in Tank-1 $\left(T_{2}\right)$ and Tank-2 $\left(T_{3}\right)$ were measured by thermocouple multi-channels. The volt-ampere-regulators were used to adjust the electrical energy in Tank-1 $\left(q_{1}\right)$ and Tank-2 $\left(q_{2}\right)$. The mathematical model was solved and rigorously examined in Xcos/Scilab. In order to study the dynamic behavior of TTTS, the inlet flowrate disturbance was made based on step input change. According to our investigation in laboratory and open loop simulation, both Tank-1 and Tank-2 gave stable responses, the model's responses showed the closed and similar trend with laboratory's responses, and dead time of about 30 seconds has been found in Tank-2.

Keywords: dead time; open loop; step input; TTTS; Xcos

\section{Introduction}

Multi-tank-series systems are often met in chemical process industries. As described by Smith and Corripio (1997), multi-capacities systems consist of two or more tanks in series, where they can be classified as either non-interacting or interacting. The system of multi-tank-series with far tanks' distance potentially produces dead time, i.e. the output variable does not respond immediately to a change in the input variable (Marlin, 2000). In addition, the other problem of multi-capacities system that probably happen is the propagation of mass and thermal disturbances (Hermawan et al, 2010 a,b). Therefore, study on the dynamic behavior of the multi-tank-series is very important to be carried out.

Two-Thermal-Tanks-Series (TTTS) with dead time produces the model of SOPDT (Second Order Plus Dead Time). Alvaro et al. (2018) has conducted dynamic simulation and level control of two-interacting-tanks system using Xcos/Scilab software. Alvaro emphasized that PID (Proportional-Integral-Derivative) method produced a stable response and faster than those in P (Proportional) and PI (Proportional-Integral) methods. Hermawan et al. (2010a,b) discussed about level and temperature dynamics in the noninteracting-tank system with recycle stream. Hermawan et al.

${ }^{*}$ Corresponding Author: +6281328525270

Email: ydhermawan@upnyk.ac.id 
$(2010 \mathrm{a}, \mathrm{b})$ reported that responses resulted by the $2^{\text {nd }}$ tank was slower than those resulted by the $1^{\text {st }}$ tank.

The most researches in the topic of dead time are frequently concerned for FOPDT (First Order Plus Dead Time) model, while researches for SOPDT model are rare. This research was aimed to study the dynamic behavior of TTTS with dead time through the open loop experiment in laboratory, and to propose the new module of fundamental chemical engineering practicum in field of process dynamic for undergraduate program. TTTS with dead time produces SOPDT model. In order to achieve our goals, we designed two stirred-tank-heaters with capacity@10 L in laboratory. Tank-1 and Tank-2 were connected with somewhat long pipe; thus, the dead time will occur in the $2^{\text {nd }}$ tank. Both of tanks were designed overflow to keep their volume constant at its their desired value. The inlet flowrate to Tank-1 $(f)$ was adjusted by a gate valve. Thermocouple (multichannels) was used to measure the inlet temperature to Tank-1 $\left(T_{1}\right)$, the liquid temperatures in Tank-1 $\left(T_{2}\right)$ and Tank-2 $\left(T_{3}\right)$. The electrical energies in Tank-1 $\left(q_{1}\right)$ and Tank-2 $\left(q_{2}\right)$ were adjusted by volt-ampere-regulators. This research was conducted in 2 parts, i.e. preliminary and open loop experiments. Preliminary experiment was done to examine the performances of all measurement devices and to get the steady state parameters. The open loop experiment was done to study the dynamic behavior of TTTS with dead time. The input flowrate disturbance was made based on a step input change. The Xcos/Scilab software was chosen to solve the developed mathematical model of TTTS with dead time. Finally, this research is hopefully useful for preliminary-design of temperature control system in TTTS with dead time, and also useful to contribute the new module of chemical engineering fundamental practicum in field of process dynamic.

\section{Material and Method}

Figure 1 shows the experimental apparatus setup. Tank No. 1 and 2 in Figure 1 represent thermal Tank-1 and Tank-2, respectively. The thermal Tank-1 has an input stream (Stream1) and an output stream (Stream-2). Stream-1 is a water fluid with its volumetric flowrate $f_{l}(t)$ [ml/second] and initial temperature of $T_{l}(t)$ [ $\left.{ }^{\circ} \mathrm{C}\right]$. The volumetric flowrate of Stream$1 f_{l}(t)$ can be regulated by adjusting the opening valve No. 7 in Figure 1, and its degree of the opening valve can be seen in the protractor No. 8 in Figure 1. The liquid in Tank-1 is heated with an electric heater No. $3 \mathrm{a}$ in Figure 1 to raise the temperature of $T_{2}(t)\left[{ }^{\circ} \mathrm{C}\right]$. The outlet stream of Tank-1 (Stream-2) with its volumetric flowrate $f_{2}(t)$ [ $\left.\mathrm{ml} / \mathrm{second}\right]$ is then flowed to Tank-2 and heated with an electric heater No. $3 \mathrm{~b}$ in Figure 1 to achieve the target temperature of $T_{3}(t)\left[{ }^{\circ} \mathrm{C}\right]$. The outlet stream of Tank-2 is Stream-3 with its volumetric flowrate $f_{3}(t)$ [ml/second] and temperature $T_{3}(t)\left[{ }^{\circ} \mathrm{C}\right]$. All temperatures of $T_{l}(t), T_{2}(t)$, and $T_{3}(t)$ are measured with thermocouple No 9a, No 9b, and No 9c in Figure 1, respectively. All measured temperature values can be seen in temperature monitor No. 10 in Figure 1 and directly recorded in the computer or laptop No. 11 in Figure 1. Both of electric energies in Tank-1 and Tank-2 can be adjusted with voltampere regulator No. $4 \mathrm{a}$ and $4 \mathrm{~b}$ in Figure 1, respectively. Stirrers No. $6 \mathrm{a}$ and $6 \mathrm{~b}$ in Figure 1 are employed in Tank-1 and Tank-2, respectively, to ensure uniform temperature $T_{2}(t)$ and $T_{3}(t)$. For the purpose of maintaining the liquid volumes in Tank-1 and Tank- 2 constant, the thermal tanks are designed overflow.

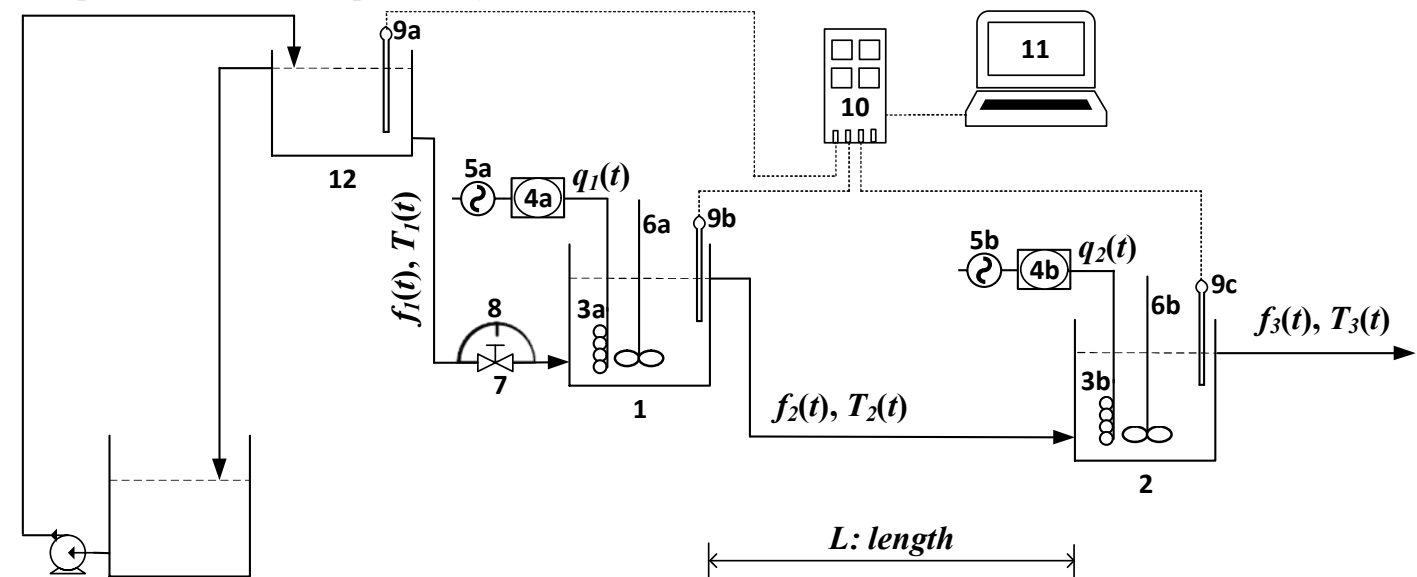

14 13
1: Thermal tank 1
2: Thermal tank 2
3: Electric heater
4: Volt-ampere regulator
5: Power source

6: Stirrer

Notes:

6: Stirrer
7: Valve
8: Protractor
9: Thermocouple
10: Temperature monitor

Figure 1. Experimental apparatus setup: two-thermal-tank-series. 
In order to achieve our goals, this research is separated into 2 steps, i.e. preliminary and open loop experiments. Preliminary experiment is aimed to examine the performances of measurement devices, i.e. protractor and thermocouple multi-channels, and to get the steady state parameters. The purpose of the open loop experiment is to explore the dynamic behavior of TTTS with dead time to a change in the inlet volumetric flowrate disturbance. The volumetric flowrate disturbance can be made by changing the opening valve No. 7 in Figure 1.

In modeling of TTTS with dead time, we assume that: liquid volumes in Tank-1 and Tank-2 are the same and constant, $V_{1}=V_{2}=V$; there is no heat loss during heating process; perfect mixing in Tank-1 and Tank-2; heat capacities for all streams are the same and constant, $C p_{1}=C p_{2}=C p_{3}=$ $C p$; densities for all streams are the same and constant, $\rho_{l}=\rho_{2}$ $=\rho_{3}=\rho$, and the volumetric flowrate for all streams are the same, $f_{l}(t)=f_{2}(t)=f_{3}(t)=f(t)$.

The linear differential equation in deviation term that represents the heat balance of Tank-1 is written below:

$$
\tau_{p} \frac{d \Gamma_{2}(t)}{d t}+\Gamma_{2}(t)=K_{1} F(t)+K_{2} \Gamma_{1}(t)+K_{3} Q_{1}(t)
$$

where process time constant $\left(\tau_{p}\right)$, process gains $K_{1}, K_{2}$, and $K_{3}$ are defined as follows:

$$
\begin{gathered}
\tau_{p}=\frac{V}{\bar{f}} \\
K_{1}=\frac{\overline{T_{1}}-\overline{T_{2}}}{\bar{f}} \\
K_{2}=\mathbf{1} \\
K_{3}=\frac{1}{\rho c_{p} \bar{f}}
\end{gathered}
$$

Deviation terms for volumetric flowrate $F(t)$, electric energy in Tank-1 $Q_{1}(t)$, liquid temperatures in Tank-1 $\Gamma_{1}(t)$ and Tank-2 $\Gamma_{2}(t)$ are defined as follows:

$$
F(t)=f(t)-\bar{f}
$$

$$
\begin{aligned}
& \mathbf{Q}_{1}(t)=q_{1}(t)-\bar{q}_{1} \\
& \Gamma_{1}(t)=T_{1}(t)-\overline{T_{1}} \\
& \Gamma_{2}(t)=T_{2}(t)-\overline{T_{2}}
\end{aligned}
$$

where $\bar{f}, \bar{q}_{1}, \bar{T}_{1}, \bar{T}_{2}$ are the initial volumetric flowrate, electric energy in Tank-1, inlet temperature to Tank-1, and liquid temperature in Tank-1, respectively.

The linear differential equation with dead time $\left(t_{D}\right)$ in deviation term that represents the heat balance of Tank-2 is written below:

$$
\tau_{p} \frac{d \Gamma_{3}\left(t-t_{D}\right)}{d t}+\Gamma_{3}\left(t-t_{D}\right)=K_{4} F(t)+K_{5} \Gamma_{2}(t)+K_{6} Q_{2}(t)
$$

where process gains $K_{4}, K_{5}$, and $K_{6}$ are defined as follows:

$$
\begin{gathered}
K_{4}=\frac{\overline{T_{2}}-\overline{T_{3}}}{\bar{f}} \\
K_{5}=1 \\
K_{6}=\frac{1}{\rho c_{p} \bar{f}}=K_{3}
\end{gathered}
$$

Deviation terms for electric energy in Tank-2 $Q_{2}(t)$, liquid temperatures in Tank-2 $\Gamma_{3}(t)$ are defined as follows:

$$
\begin{aligned}
& \mathbf{Q}_{2}(t)=q_{2}(t)-\bar{q}_{2} \\
& \Gamma_{3}(t)=T_{3}(t)-\bar{T}_{3}
\end{aligned}
$$

where $\overline{\boldsymbol{q}}_{\mathbf{2}}, \overline{\boldsymbol{T}}_{\mathbf{3}}$ are the initial electric energy in Tank-2 and liquid temperature in Tank-2, respectively.

The laplace transform of equations (1) and (10) are:

$$
\begin{aligned}
& \Gamma_{2}(s)=\frac{K_{1}}{\left(\tau_{p} s+1\right)} F(s)+\frac{K_{2}}{\left(\tau_{p} s+1\right)} \Gamma_{1}(s)+\frac{K_{3}}{\left(\tau_{p} s+1\right)} Q_{1}(s) \\
& \Gamma_{3}(s)=\frac{K_{4} e^{-t_{D} s}}{\left(\tau_{p} s+1\right)} F(s)+\frac{K_{5} e^{-t_{D}} s}{\left(\tau_{p} s+1\right)} \Gamma_{2}(s)+\frac{K_{6} e^{-t_{D}}}{\left(\tau_{p} s+1\right)} Q_{2}(s)
\end{aligned}
$$

Block diagram of TTTS with dead time is shown in Figure 2. The model system as shown in block diagram of Figure 2 is then solved with $\mathrm{Xcos} / \mathrm{Scilab}$ software.

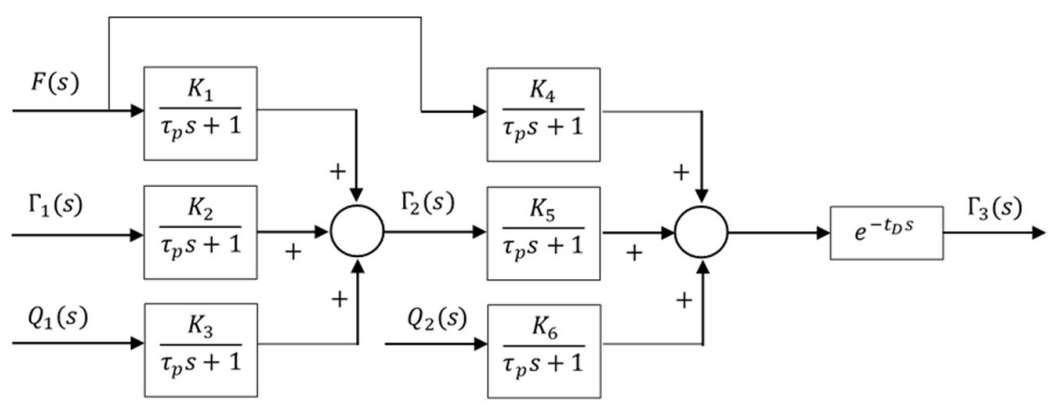

Figure 2. Block diagram of TTTs with dead time.

\section{Result and Discussion}

Calibration curve of the relationship between opening valve and volumetric flowrate is shown in Figure 3. The calibration curve shows that the used control valve has a linear characteristic. According to this calibration, the maximum fluid flows in this apparatus set up is $187 \mathrm{ml} / \mathrm{s}$ with maximum opening valve $60^{\circ}$. If the opening valve is higher than $60^{\circ}$, fluid will overflow and out of Tank-1. In order to ensure that all thermocouples have the same performance, those thermocouples were examined through experiment of heating water in a $1 \mathrm{~L}$ stirred glass. The performance of 4 thermocouples are shown in Figure 4. As shown in Figure 4, the temperature values of all thermocouples are almost the same. This implies that the 4 thermocouples have the same quality, so they can be used to measure the temperature at different location.

The steady state parameters of TTTS with dead time are listed in Table 1. The steady state parameters are then used to calculate process time constant and gain as shown in Table 2. As described by Stephanopoulos (1984), The smaller the value of process time constant and the bigger the value of 
process gain, the more sensitive the process to a change in the input disturbance. As shown in Table 2, The process time constants $\left(\tau_{p 1}\right.$ and $\left.\tau_{p 2}\right)$ are found rather high, about 101.64 seconds; and the process gains $K_{1}$ and $K_{3}$ are low, about 0.017 and 0.003 , respectively. Therefore, this system is considered less sensitive to the input disturbances.

The steady state parameters of TTTS with dead time are listed in Table 1 . The steady state parameters are then used to calculate process time constant and gain as shown in Table
2. As described by Stephanopoulos (1984), The smaller the value of process time constant and the bigger the value of process gain, the more sensitive the process to a change in the input disturbance. As shown in Table 2, The process time constants ( $\tau_{p 1}$ and $\tau_{p 2}$ ) are found rather high, about 101.64 seconds; and the process gains $K_{1}$ and $K_{3}$ are low, about 0.017 and 0.003 , respectively. Therefore, this system is considered less sensitive to the input disturbances.

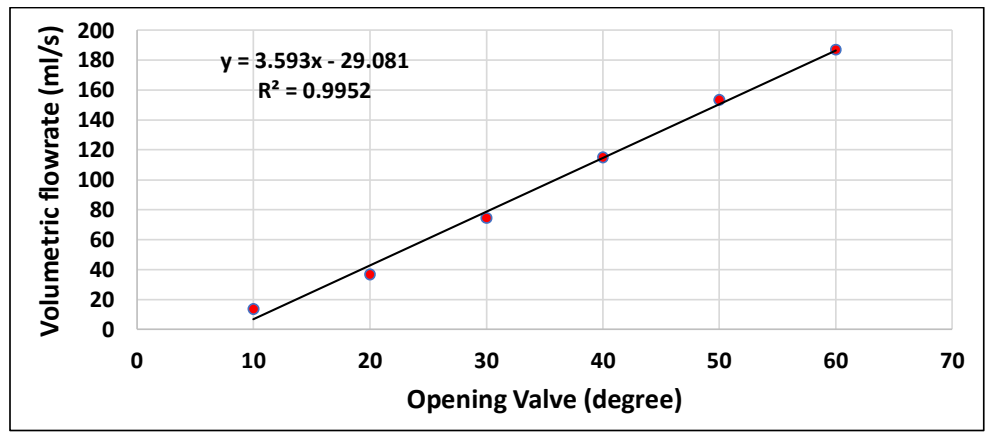

Figure 3. Calibration curve of the relationship between opening valve and volumetric flowrate.

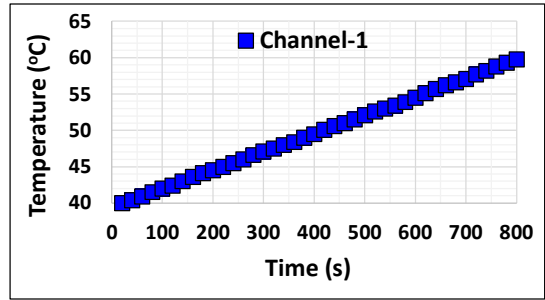

a. Channel-1

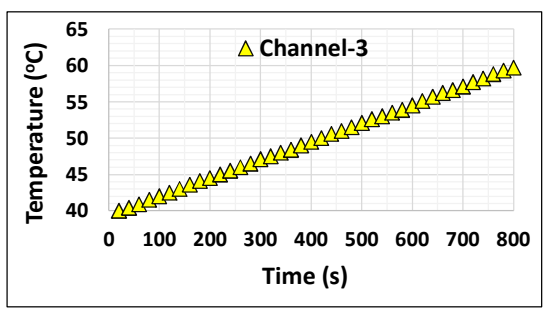

c. Channel-3

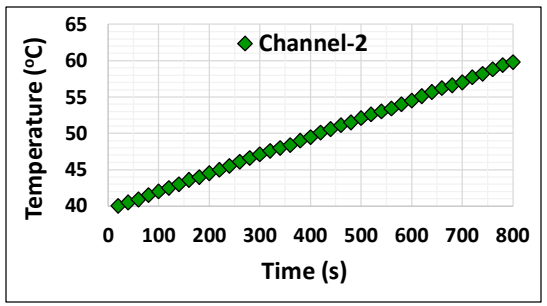

b. Channel-2

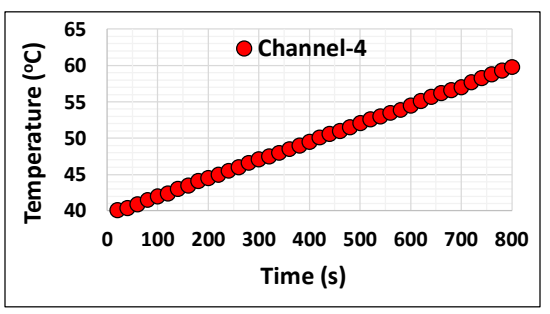

d. Channel-4

Figure 4. Performance of thermocouple 4 channels.

Tabel 1. Steady state parameters

\begin{tabular}{ccc}
\hline No. & Variable & Value \\
\hline 1 & Volumetric flowrate of fluid, $f(\mathrm{ml} / \mathrm{s})$ & 78.709 \\
2 & Liquid volume in Tank- $1, V_{l},(\mathrm{ml})$ & 8000 \\
3 & Liquid volume in Tank-2, $V_{2},(\mathrm{ml})$ & 8000 \\
4 & Energy of electric heater in Tank-1, $q_{l}(\mathrm{~J} / \mathrm{s})$ & 400 \\
5 & Energy of electric heater in Tank- $2, q_{2}(\mathrm{~J} / \mathrm{s})$ & 400 \\
6 & Inlet temperature to Tank- $1, T_{l}\left({ }^{\circ} \mathrm{C}\right)$ & 29 \\
7 & Liquid temperature in Tanki-1, $T_{2}\left({ }^{\circ} \mathrm{C}\right)$ & 30.4 \\
8 & Liquid temperature in Tank-2, $T_{3}\left({ }^{\circ} \mathrm{C}\right)$ & 31.3 \\
9 & Liquid density, $\rho(\mathrm{g} / \mathrm{ml})$ & 0.997 \\
10 & Liquid heat capacity, $\mathrm{C}_{\mathrm{p}}\left[\mathrm{J} /\left(\mathrm{g} .{ }^{\circ} \mathrm{C}\right)\right]$ & 4.185 \\
\hline
\end{tabular}


Eksergi, Vol 17, No. 2. 2020

ISSN: $1410-394 \mathrm{X}$

Tabel 2. Process time constant and gain

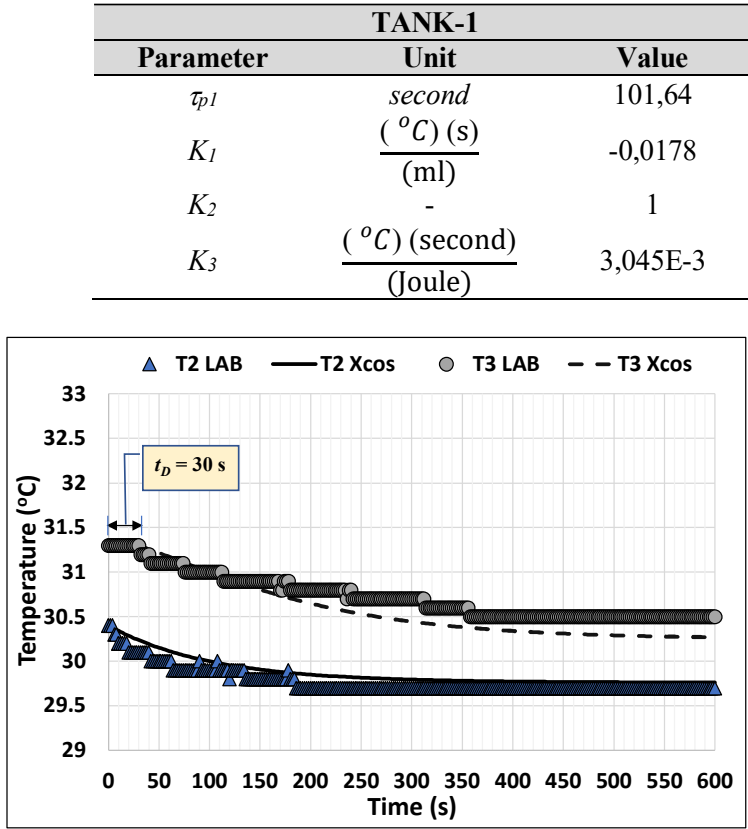

(a)

\begin{tabular}{ccc}
\hline & TANK-2 & \\
\hline Parameter & Unit & Value \\
$\tau_{p 2}$ & second & 101,64 \\
$K_{4}$ & $\frac{\left({ }^{o} C\right)(\mathrm{s})}{(\mathrm{ml})}$ & $-0,0114$ \\
$K_{5}$ & - & 1 \\
$K_{6}$ & $\frac{\left({ }^{o} \mathrm{C}\right)(\text { second })}{\text { (Joule) }}$ & $3,045 \mathrm{E}-3$ \\
\hline
\end{tabular}

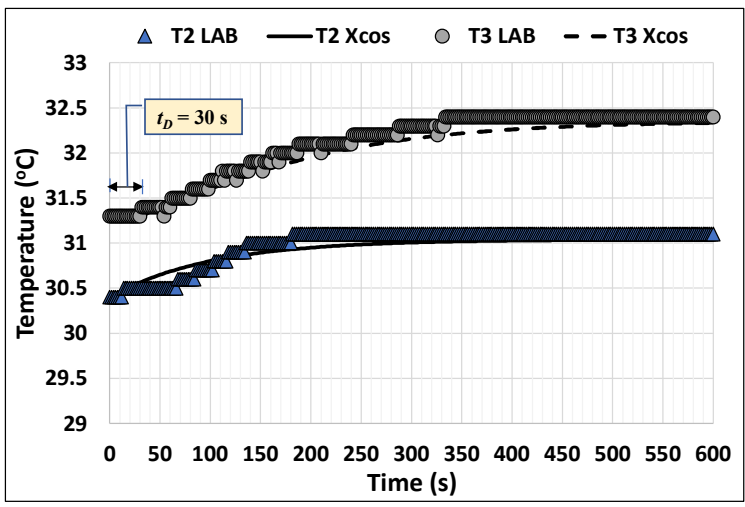

(b)

Figure 5. Open loop response to: (a) a step increase and (b) a step decrease, change in $f(t)$.

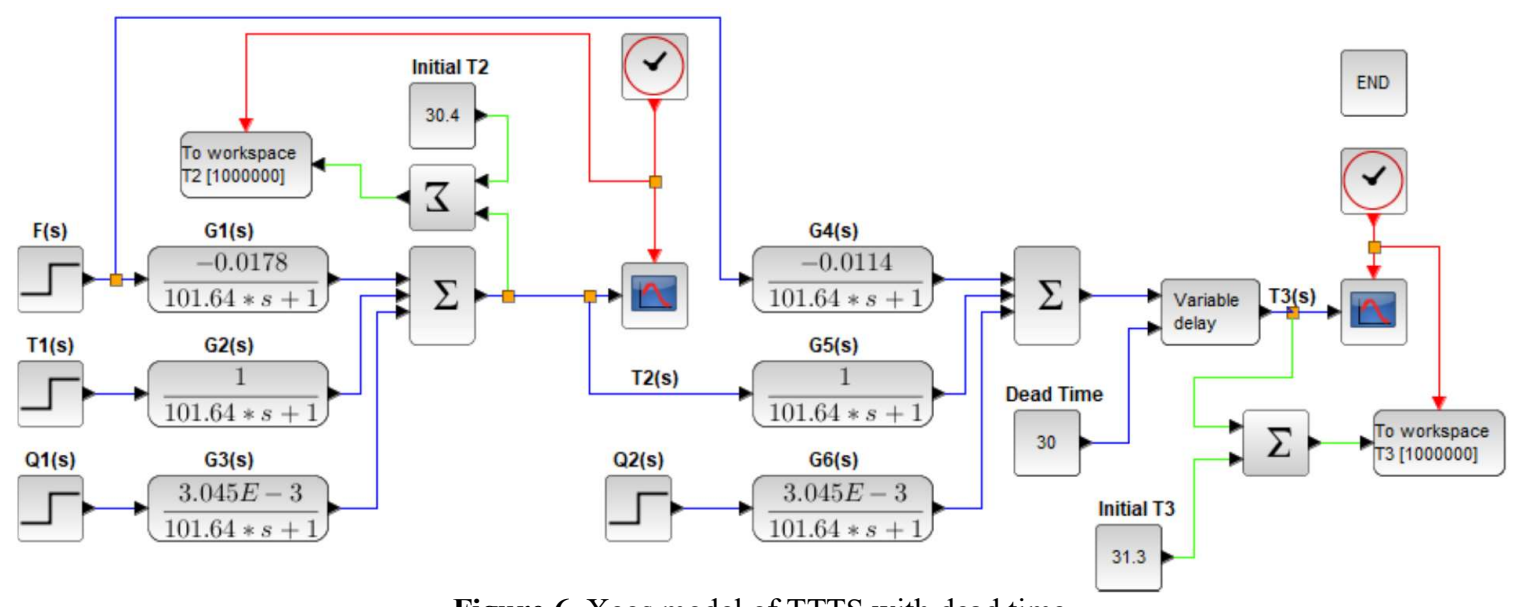

Figure 6. Xcos model of TTTS with dead time.

The open loop responses to a step increase change in volumetric flowrate $f(t)$ are shown in Figure 5(a). The disturbance load is increased $45.6 \%$, i.e. from $78.7 \mathrm{ml} / \mathrm{s}$ to $114.6 \mathrm{ml} / \mathrm{s}$. As shown in Figure 5(a), the liquid temperatures in Tank-1 $T_{2}(t)$ and Tank-2 $T_{3}(t)$ decrease by increasing the volumetric flowrate $f(t)$. The temperature $T_{2}$ achieves the new steady value of $29.6^{\circ} \mathrm{C}$ at time about 200 seconds, while $T_{3}$ achieves the new steady value of $30.5{ }^{\circ} \mathrm{C}$ at time about 340 seconds.

Figure 5(b) shows the open loop responses to a step decrease change in volumetric flowrate $f(t)$. The disturbance load is decreased $45,6 \%$, i.e. from $78.7 \mathrm{ml} / \mathrm{s}$ to $42.8 \mathrm{ml} / \mathrm{s}$. The liquid temperatures in Tank-1 $T_{2}(t)$ and Tank-2 $T_{3}(t)$ increase by decreasing the volumetric flowrate $f(t)$ as shown in Figure 5(b). The temperature $T_{2}$ reaches the new steady value of $31.1{ }^{\circ} \mathrm{C}$ at time about 200 second, and $T_{3}$ reaches the new steady value of $32.4^{\circ} \mathrm{C}$ at time about 340 seconds.

Based on our investigation, there is a time interval of about 30 seconds during which no effect is observed on the liquid temperature in Tank- $2 T_{3}(t)$. This time interval is known as dead time or pure delay. This delay is caused by the length of pipe between Tank-1 and Tank-2 which quiet long. Since the dead time is one of instability sources in dynamic point of view, its presence needs to be anticipated.

Figure 6 shows the Xcos model of TTTS with dead time. The Xcos' responses are recorded and directly showed by palette CSCOPE. In addition, the digital data can also be saved in WORKSPACE, its results are then copied in 
EXCEL software for further editing. The solid and dashed line in Figure 5 show response of temperature $T_{2}(t)$ and $T_{3}(t)$, respectively, to a change in step increase/decrease of volumetric flowrate $f(t)$. As can be seen from Figure 5, the Xcos' responses have the same trend and somewhat close with laboratory's responses.

\section{Conclusion}

The open loop experiment of TTTS with dead time has been successfully done in laboratory. The process time constant was found about 101.64 seconds. Since the process time constant was found somewhat high, the process system was considered less sensitive to a change in the input disturbance. According to our investigation, both Tank-1 and Tank-2 produced stable responses to step input change in volumetric flowrate. But, the dead time of about 30 seconds was found in Tank-2. The Xcos model gave the similar responses with laboratory's responses. In order to improve our study, the dynamic simulation and control of TTTS with dead time is necessary to be done in the future.

Showing that simple experiment of TTTS with dead time can be easily done in laboratory, allowing students to do other similar case for the future applications. According to the results of open loop experiment in laboratory and simulation with $\mathrm{Xcos} / \mathrm{Scilab}$, this study is considered useful for designing of process control configuration in TTTS with dead time for the future work. This study is also strongly recommended to complete the material of fundamental chemical engineering practicum in field of process dynamic for undergraduate program. The students will have good experience in both laboratory and simulation using $\mathrm{Xcos} /$ Scilab

\section{Acknowledgments}

The financial support from Institute for Research and Community Development of Universitas Pembangunan Nasional "Veteran" Yogyakarta for this research is gratefully acknowledged. We appreciate the technical support on the use of free software of Xcos/Scilab. We also thank Pratiwi H., and Nufus Y. for helping us during our research in laboratory.

\section{References}

Alvaro R. J., María A. M., and David F. B., 2018, Level Control in A System of Tanks in Interacting Mode Using Xcos Software, Contemporary Engineering Science, Vol.11 No.2: 63-70 DOI: https://doi.org/10.12988/ces.2018.712206

Hermawan Y. D.; Suksmono Y., Dewi D. U., dan Widyaswara W., 2010a, Dinamika Level Cairan pada Sistem Tangki-Seri-Tak-Berinteraksi dengan Arus Recycle, Seminar Nasional Teknik Kimia "Kejuangan", ISSN: 1693-4393, Jurusan Teknik Kimia, Fakultas Teknologi Industri, UPN "Veteran” Yogyakarta, D08-1D08-6.

http://jurnal.upnyk.ac.id/index.php/kejuangan/article/vie $\underline{w} / 529$

Hermawan Y. D., Suksmono Y., Sulistyawati E., Cicilia E., and Aisyiah D. S., 2010b, Dinamika Suhu pada Sistem Tangki-Seri-Tak-Berinteraksi dengan Arus Recycle, Seminar Nasional Teknik Kimia "Kejuangan", ISSN: 1693-4393, Jurusan Teknik Kimia, Fakultas Teknologi Industri, UPN "Veteran" Yogyakarta, D10-1-D10-6. http://jurnal.upnyk.ac.id/index.php/kejuangan/article/vie $\mathrm{w} / 528$

Marlin, T. E., 2000, Designing Processes and Control Systems for Dynamic Performance, $2^{\text {nd }}$ ed., McGraw-Hill, USA, p. 103, 143-152.

Scilab software available at www.scilab.org

Smith, C. A., and Corripio, A. B., 1997, Principles and Practice of Automatic Process Control, $2^{\text {nd }}$ ed., John Wiley \& Sons, Inc., USA, p. 135-196.

Stephanopoulos, G., 1984, Chemical Process Control: An Introduction to Theory and Practice, PTR. Prentice-Hall, Inc., A Simon and Shuster Company, New Jersey, p. 173211. 